\title{
ECONOMY
}

IRSTI 06.35.31 https://doi.org/10.26577/CAJSH-2019-4-s1

\author{
Khalel A., Işıl Altun \\ Doctor of pedagogical sciences, professor Kocaeli University, Turkey, e-mail: isilaltun@hotmail.com
}

\section{INTERCULTURAL SHOLARLY DISCUSSION AS AN OBJECT OF METHODOLOGICAL MODELLING IN FLT}

\begin{abstract}
The article deals with the problems of methodological modeling of intercultural scientific discussion in a foreign language as an international academic measure implemented through intercultural academic interaction of representatives of various cultural,linguistic and research communities. For professional-branch communicative preparation of students of language specialties for effective participation in this scientific event in a foreign language it is necessary: a) to determine the conceptual content of the term "intercultural scientific discussion"; b) to identify the nomenclature of sequential fragmentation of intercultural communicative macro education in the micro education term on the basis of didactic-oriented content analysis of the system of activity for participants of intercultural scientific discussion in the socio-cultural academic role; c) to identify the main types of professional task assignments (in the context of international and national universities standards) created by a hierarchical system of foreign language for consistent and dynamic communicative and cognitive development of students as an equal participant of intercultural academic communication.

Key words: intercultural academic communication, intercultural scientific discussion, socio-cultural academic roles, intercultural communicative macro and micro educations, professional-profile and cultural-oriented problem tasks.
\end{abstract}

Introduction. The need for active and productive participation of Kazakhstan in modern global civilization programs such as "Open Education" and "Open Science", "Open Innovations", "Opening to the World" set a number of challenges for higher education. They are: to train specialists who are ready and capable for effective professional intercultural interaction in the context of cultural and civilized dialogue in today's globalized world, where geopolitical, cultural, linguistic, religious and political-economic contradictions are worsening, and information wars in human world outlook. From the earliest times, debate is considered to be the most effective form of dealing with a controversial issue that arises in human life and is an integral part of the humanitarian education and partly linguistic knowledge. So far, the focus has been on general issues of the teaching methodology and the discussion of the methodological potential of this language form as a developer of communicative tools. Therefore, in the context of intercultural competence, dynamically focused on such levels of higher education as magistracy, doctoral studies, but special attention was not paid to the problems of formation and development of academic discussion in higher education. This article deals with the basics of academic discussion in a foreign language, methodological modeling of the behavior of participants of scientific academic debate and international norms of interaction for the discussion in accordance with their social and cultural academic roles.

Literature review. Methodological interest in the study of the debate in foreign language appeared in the 70 s of the last century, and it contributed to the publication of the first methodological works about the discussion in the teaching system of foreign language. Thereafter, this issue has been a subject of research in the field of language pedagogy. As a result, P. B. Gurvich, E. V. Shantarina, N. E. V. Shuvalova, E. V. In Smirnova's works it became possible to define a certain set of discussion skills and offer forming and developing tasks on the basis of the studied foreign language material. The methodological significance of these works is still high. However, it should be noted that in the 
works of the above-mentioned authors were not paid attention to many objective and subjective reasons of intercultural aspect. However, it is doubtful whether it is possible to create a methodical model of teaching students academic discussion, which is important for the effectiveness of intercultural academic discussion in the context of civilization and the modern multilingual and multicultural world, striving for "Open education", "Open science", "Open innovation", without paying full attention to this issue. At the same time, in the field of domestic linguistics, there is still a tendency to ignore the intercultural aspect of teaching discussions using methodological researches in Universities. This process continues in domestic science, despite the fact that such universal competencies as "communication" and "intercultural interaction" (in the formation of these competencies, the University plays a key role in language teaching), are manifested as educational results in all languages studied in the Universities. When studying intercultural scientific discussion in the intercultural aspect of modeling, it is necessary, first of all, to pay attention to the linguistic meaning of this term. In this article, intercultural scientific discussion is understood as a type of discourse functioning in the language space of international professional and scientific events (international scientific conference or international scientific seminar), the main purpose is a group or collective assessment of theoretical and applied scientific results or analysis of the achievement of academic consensus in the process of their ethnic/ super ethnic, regional, continental, religious and geopolitical cultural and linguistic interaction of representatives of cultural and linguistic subcultures. In the process of intercultural scientific discussion communicators solve many communicative and high communicative professional tasks:
- to analyze actual problems in the work of a particular scientific school and issues of interest from a scientific point of view (including certain parts of the discussion interaction) and the results.

- the possibility of research and scientific consensus on the most controversial conceptual rules.

- Establishing and maintaining cooperation for further professional communication with colleagues in virtual and non-virtual space, exchange of professional experience.

Material and Methods. While modeling intercultural scientific debate in terms of foreign training of students of a magistracy it is advisable to divide intercultural communicative macro education into micro educational level. To analyze of original materials, video recordings of the scientific discussion (which took place at international conferences and scientific and methodological seminars in English or appropriate languages in 2014-2018) and identify the nomenclature of intercultural communicative macro-and micro education of the organizers and other participants of the scientific discussion for linguo-didactic purposes, as well as the definition of their range in the performance of various sociocultural academic roles (Afuach 2003:86 p). Based on the expertise of international scientific and practical seminars initiated by the European Council and the European Union, we include the following roles which are in the socio-cultural academic role:

- Chairman and / or Leading Organizer;

- Expert / experts;

- Moderator / group of moderators;

- Facilitator/group of facilitators;

- Representatives of scientific schools and national academic associations.

There are main macro and micro educational nomenclature common to most participants of international science workshops associated with their specific cross-cultural roles (Table):

Table 1 - The system of activity for organizing scientific discussions

\begin{tabular}{|l|l|l|}
\hline \multicolumn{1}{|c|}{ Macro education } & \multicolumn{1}{c|}{ Micro education } & \multicolumn{1}{c|}{ Socio-cultural academic roles } \\
\hline $\begin{array}{l}\text { To organize academic } \\
\text { discussions based on } \\
\text { the cultural and social } \\
\text { background of the } \\
\text { participants; }\end{array}$ & $\begin{array}{l}\bullet \text { to meet participants of scientific discussion as } \\
\text { representatives of different cultural/cultural-linguistic } \\
\text { communities; } \\
\bullet \text { to interpret the relevance of scientific discussion topic; } \\
\bullet \text { to distinguish the problem parts of the academic debate; } \\
\bullet \text { to interpret organizational forms of interaction (if it is } \\
\text { necessary); } \\
\bullet \text { to strict compliance with the temporary rules of } \\
\text { academic interaction in the format of scientific discussion. }\end{array}$ & $\begin{array}{l}\bullet \text { Presiding director/organizer of the } \\
\text { scientific discussion. } \\
\end{array}$ \\
\hline
\end{tabular}




\begin{tabular}{|l|l|l|}
\hline $\begin{array}{l}\text { To present moderators, } \\
\text { facilitators, experts to the } \\
\text { audience; }\end{array}$ & $\begin{array}{l}\bullet \text { to use cultural and social formulas for moderators and } \\
\text { experts properly; } \\
\text { to provide accurate information about the scientific } \\
\text { achievements of experts and moderators, their valuable } \\
\text { work in the real science and pedagogical activity. }\end{array}$ & $\begin{array}{l}\bullet \text { Presiding director/organizer of the } \\
\text { scientific discussion. } \\
\text { Invited Experts. }\end{array}$ \\
\hline $\begin{array}{l}\text { The ability to summarize } \\
\text { the results of intercultural } \\
\text { research; }\end{array}$ & $\begin{array}{l}\bullet \text { to ask a number of research questions that require } \\
\text { cooperation and collaboration in research and education. } \\
\text { To determine the main results obtained in the course of } \\
\text { scientific discussion; } \\
\bullet \text { To express appreciation to the participants of the } \\
\text { intercultural scientific debate for the discussion of main } \\
\text { problems for the development of modern science; }\end{array}$ & $\begin{array}{l}\bullet \text { Presiding director/organizer of the } \\
\text { scientific discussion. } \\
\bullet \text { Invited Experts. }\end{array}$ \\
\hline $\begin{array}{l}\text { To express final words of } \\
\text { gratitude on the results } \\
\text { of intercultural scientific } \\
\text { discussion; }\end{array}$ & $\begin{array}{l}\text { to use polite forms of communication with representatives } \\
\text { of academic communities correctly; } \\
\bullet \text { To thank for the opportunity to participate in cross- } \\
\text { cultural scientific discussion, obtained in the intercultural } \\
\text { academic relations; } \\
\bullet \text { To determine the importance of intercultural scientific } \\
\text { discussion in the development of modern science; } \\
\bullet \text { To use appropriate non-verbal communication tools; }\end{array}$ & $\begin{array}{l}\bullet \text { Presiding director/organizer of the } \\
\text { Invited Experts. }\end{array}$ \\
\hline
\end{tabular}

In accordance with the current regulatory and methodological strategy of higher education, the participants of the scientific discussion in a foreign language acquire socio-cultural academic roles if they have mastered it before the master's and doctoral studies, as a specialty at the bachelor's level (Chesbrough 2006:50). And at the master's level, it is planned to master academic roles by directing participants of interaction debate, but in doctoral studies this process will be mastered in the system of activities of academic roles, facilitators, moderators aimed at experts. However, it is connected with micro education and professional foreign language that determine the communicative-pragmatic minimum of verbal and non-verbal thinking, combined with a specific macro education and linguo-cultural format.

Results and Discussion. In the absence of the above conclusion "Vocational training, a professionally-oriented complex of problemcommunicative tasks necessary to ensure the rational and effective participation of undergraduate students majoring in intercultural linguistic, cultural and research environment with representatives of the academic community in the research environment that has been focused on the needs to integrate competence and problem positions, allowing to create tools for methods of creating a problem-oriented environment that meets the regulatory and methodological requirements of the professional standard" Teacher of vocational education and additional vocational education" the desire would be a utopia.

Mastering the system of interaction debate, especially in conditions of intercultural academic communication is a complex of methodological system that requires the creation of a hierarchical system of professionally-oriented problem communicative tasks to prepare students of language specialties for intercultural academic communication (DasilvaM.C. 2013: 13). Therefore, when modeling intercultural scientific discussion of linguo-didactic purpose in this issue it is rational to use the following:

1. Cultural-oriented communicative tests (B2) (aimed at developing the ability of the communicative-linguistic competence to select adequate linguistic means of expression in debates related to intercultural discussion);

2. Professionally-oriented cultural,educational and search tasks (contributing to the development of control of verbal and non-verbal activities of participants for intercultural scientific discussion in foreign language, the generalization of their communicative and pragmatic observations, the definition and generalization of the activities of participants for the scientific discussion and the Chief-organizer of the scientific seminar, moderators and facilitators in the case perform their academic functions);

3. Professionally-oriented communicative and pragmatic tasks (including the search for ways to overcome the communicative and cognitive barriers typical of Kazakh people in interaction with representatives of other academic linguo-cultural communities, formed on the materials of problem situations in the framework of the international scientific seminar, as well as the definition of professional and communicative tasks necessary to solve by communicators in the process of academic interaction); 
4. Academic role-playing games aimed at learning the real socio-cultural academic roles;

5. To research case study involved in the process of modeling the scientific seminar as a communicative event, characterized by well-established and strictly regulated rules of the academic game.

Conclusion. So, the nomenclature of intercultural communicative knowledge recommended as a result of the linguo-cultural description of intercultural academic discussion and its combination with the main socio-cultural academic roles, as well as professionallyoriented problem communicative tasks are necessary prerequisites for the design of a holistic model of training students to intercultural communication with representatives of various linguistic and cultural academic communities in foreign language.

\section{References}

Afuah, A. (2003). Business Models: A Strategic Management Approach. New York: McGraw-Hill/ Irwin. Baden-Fuller, CH. \& Morgan, M. S.

Chesbrough, H. (2006). Open Business Models: How to Thrive in the New Innovation Landscape. Boston: Harvard Business School Press. Debelak, D.

DaSilva, M.C. and P. Trkman (2013).LongRangePlanning. Business Model: What It Is and What It Is Not (1-11).

Korošová, V. \& Synek, V. (2011). Grécky oikos a nevalný val. Trend, No. 29

Magretta, J. (2010). Why Business Models Matter. Harward Business Review on Business Model Innovation. USA: HBR Publishing Corporation.

Mullins, J. \& Komisar, R. (2009). Getting to Plan B: Breaking Through to a Better Business Model. USA: Harvard Business Press.

Onetti, A., A. Zucchella, V.J. Marian and P.P. McDougall-Covin (2012). Journal of Management and Governance. Internationalization, innovation and entrepreneurship: business models for new technology-based firms, Journal of Management \& Governance, 3: 337-368.

Teece, J. D. (2010). Business Models, Business Strategy and Innovation. Long Range Planning, 43(2), 172-194. http://dx.doi. org/10.1016/j.lrp.2009.07.003

Rappa, M. (2010). Business Models on the Web. Retrieved May 17, 2010, from http:// digitalenterprise.org/models/models.html 1. 2. 3. 4. 5. 6. 7. 8. 9. 10. 11. 12. 13. 14. 15. joc4-2014_v3b.indd 39 30.12.2014 17:11:25 40 Journal of Competitiveness

Slávik, Š. (2011). Komparatívna analýza podnikatel’ských modelov. Ekonomika a manažment, 11(3), 23-43.

Slywotzky, A.J. (1996). Value Migration, Harvard Business Review Press,Boston,MA.

Xavier L., D. Benoit and J. Ventura (2010). M@n@gement. Business Models as a Research Program in Strategic Management: An Appraisal based on Lakatos, vol. 13 no. 4: 214-225.

Zott, C. and R. Amit (2010). LongRangePlanning. Business Model Design: An Activity System Perspective, 43: 216-226.

Watson, D. (2005). Business Models. Petersfield: Harriman House Ltd. www.science.kz 